\title{
"A Qualitative Study on the Impact of a Good Remuneration Package to Public Servants on the Enhancement of the Delivery of Public Services"
}

\author{
Article by Amanda Jaisingh \\ Management, Texila American University \\ E-mail: ajaisingh@texilaconnect.com
}

\begin{abstract}
The government of any country such as Guyana has a fundamental right in providing public services and goods to its people.

The title for this study was: "A qualitative study on the impact of a good remuneration package to public servants on the enhancement of the delivery of public services." They were many objectives but the main one was "To determine if a good remuneration package to public servants will lead to the enhancement in the delivery of services to the public."

Great attention has been paid to remuneration package and its impact on the delivery of services within the public service of many countries, e.g. Guyana. Problems experiences were many, for example employees' benefits were not sufficiently competitive to retain well experienced staff members. Therefore, in order to bring clarity to the problems, the researcher developed and answered five research questions.

The study was qualitative in nature. The secondary data was collected from many sources and the researched countries public services were Guyana, Trinidad and Tobago, The General Caribbean, etc.

The major findings discovered were that in almost all public service in the world there were massive public sector reform to tackle work performance and delivery of services. The researcher interprets and concludes that there is a strong relationship between public servants receiving a good remuneration package and its enhancement in the delivery of the public service to the people. However, governments should not totally depend on remuneration package but look at other means.
\end{abstract}

Keywords: Public Service, Remuneration Package, Public Officer, Public Office, Public goods and services.

\section{Introduction}

The public service is a service or goods provided by any government to the people of its country. Salaries and benefits are paid to public servants all over the world to deliver effectively on the job thus bringing total satisfaction to the citizens of a country as it relates to the services or goods they received. The way the service and goods being delivered and the satisfaction it brings to the people of a country will portray the image of the public service. It therefore means the salaries and benefits are very important for the employer and employees in the government of any country such as Guyana and public servants. To the employer/government, once an attractive package is being paid, there will be job satisfaction, motivation, low absenteeism and low turnover of public servants in the public service. On the other hand, it will benefit the public servants by increasing their self-confidence, increase purchasing power and peace of mind. With this in mind, the researcher title for this study is: "A qualitative study on the impact of a good remuneration package to public servants on the enhancement of the delivery of public services."

Countries public services chosen for this document research were Guyana, Trinidad and Tobago, The General Caribbean, Gulf countries/Gulf Cooperation Council (GCC), Republic of South Africa, Kenya and Nigeria. They were researched to get a comprehensive knowledge on the impact of a good remuneration package to public servants on the enhancement of the delivery of public services. The public service in any country has almost the same structure. For example, in Guyana, the public service is composed of ministries with divisions and departments under their control, regional administrations, public corporations, financial entities, constitutional agencies, and military and police 
services. Most of the divisions and departments report to their respective ministers through their hierarchies, some ministries contain autonomous departments whose heads report directly to the Minister. The public service of Guyana consists mostly of public corporations, governed under the Public Corporations Act of 1988. They are either employed on the pensionable or non-pensionable establishment and are paid on a salary scale of G.S 1 to 14, with one being the lowers or entry level workers and 14 be the highest such as Permanent Secretaries. The employees were spread over one thousand and thirty seven $(1,037)$ different job titles and in five (5) categories namely, Administrative, Senior Technical, Other Technical and Craft Skilled, Clerical and Office Support and Semi-skilled Operatives and Unskilled.(Report on the Commission of Inquiry into the Public Service of Guyana, 2016).

\section{Background}

There has been great attention within the public service of many countries by the various ruling government as it relates to remuneration package and its impact on the delivery of services. One such country public service was Guyana where it was captured in the Guyana Public Sector Modernization Programme and of most recent the Commission of Inquiry (COI) into the Public Service of Guyana. In 2002, the government of the day undertook an initiative to modernize the entire public sector more specifically the public service in which a massive donor-funded consultancy was contracted to guide the entire process. It proposed a vision that shows that within ten years, the Guyana Public Service will be a customer driven institution, providing quality services for the economic stability and sustained development of Guyana through the twenty-first century. The Public Service will be small, comparatively well paid, efficient and effective, undertaking planning, supervisory and regulatory functions, facilitating and encouraging investment and the private sector, and operating within sustainable cost limits related to national economic performance.

The Government of Guyana has undertaken some major exercises to improve the remuneration structures in the public service. They revised first, the salary structure in 1993 and later approved a series of wage increases since 1994. This was done to correct the real wage declines in the public sector in the 1980s and early 1990s. Additionally, wage supplements were granted over base pay to critical positions. This wage reform was to achieve the medium-term goal of bringing public sector wages gradually to within 10 percent of the median for comparable jobs in the private sector. (World Bank Report, 1995) Many public offices in the public service tried to compensate for the low salaries through granting ad hoc benefits and allowances to supplement salary with the intention that public servants will be adequately paid so that they will perform better on the job to deliver excellent services to the public. For example, some of the benefits given in the public service are travelling allowance, duty allowance, entertainment allowance, responsibility allowance, acting allowance, sick leave with full or half pay, vacation/annual leave Allowance, overtime allowance, time off with pay or without pay, pension upon retirement, entitlement of 28 days sick leave concession and many others. Some positions even attract duty free concession.

Therefore, the relationship between remuneration package and the enhancement of services cannot be overlooked and overemphasized. According to the Trinidad and Tobago Civil Service Act Chapter 23:01 which stated that the term remuneration means pay and allowances. (Trinidad and Tobago Civil Service Act Chapter 23:01).

\section{Problem}

Public Servants such as in Guyana are either employed on the pensionable establishment or on contract and are paid on salary scales. In Guyana, the salary scale range from G.S 1 to 14, with one being the lowers or entry level workers and 14 be the highest such as Permanent Secretaries. Both pensionable and non-pensionable employees benefit from acting allowances when performing higher duty, they can also be paid a responsibility allowance for performing additional duties other than their own.

The problems experienced in many countries public services are many. Public servants were being paid to deliver goods and services to the general public in an effective and efficient manner so that the public will be satisfied with the services they received but it clearly appears that employees' benefits 
in public service such as Guyana were not sufficiently competitive to retain well experienced staff members and even in the delivery of services. The public sectors in many countries have experienced dramatic expansion in both its functions and its size. The quality of the service being delivered to the public has deteriorated and the principal cause is the low remuneration package given to public servants. Over the past few years, public services across the world has seen a lot of brain drain where many of its skilled and technical workers such as teachers, nurses, engineers, and many others categories of workers are migrating to greener pastures in the Caribbean, North America and Europe. Public servants were seen picketing in front of their ministries and Unions, fighting for better wages and salaries which do not portray a good image of the public service. Unions in some countries such as the Guyana were in constant fight with their Government for better wages and salaries for public servants on a yearly basis but have achieved little results in this battle. In some countries, the government of the day will usually imposed salary increases for public servants before the unions complete their negotiation. There were no effective policies that were in place to motivate public servants to deliver on the job such as the performance appraisal and workers increments. Performance Appraisals has become an absolute and outdated performance measurement instrument to test workers performance on the job and not many Personnel Practitioners were trained to use their current performance appraisal system. No formal needs analysis was done in some public service to determine why workers were not performing to the best of their ability and why the public was not satisfied with the services they were receiving. On many occasions one would hear the general public complaining about the length of time and paper work to be completed for services required and the manner in which they were treated by public servants were questionable. The use of technology and customer service training were lacking at every level in the delivery of services in some of the research countries. In this modern era of technology and the internet, one will asked, if technology was ever given a thought in the service delivery.

As a result of the problems highlighted above, the researcher was prompted to carry out this qualitative study on the impact of a good remuneration package to public servants on the enhancement of the delivery of public services by carrying out a qualitative document research on countries such as Guyana, Trinidad and Tobago, The General Caribbean, Gulf countries/Gulf Cooperation Council (GCC), Republic of South Africa, Kenya and Nigeria.

In order to bring clarity to the subject under discussion, the following research questions were developed and answered:

1. What can be considered a good remuneration package for public servants?

2. What policies are in place to motivate public servants to deliver effective services?

3. What systems are in place to monitor public servants in order to deliver effectively on the job?

4. Who determines a good remuneration package for public servants?

5. What indicators are used to determine public satisfaction with service received?

\section{Purpose/Significance}

The government of any country such as in Guyana has a fundamental right in providing public services and goods to its people. However, the delivery of this service and goods will portray the image of the public service. Therefore, remuneration is being paid to public servant to deliver effectively and efficiently on the job.

The objectives of this study were "To determine if a good remuneration package to public servants will lead to the enhancement in the delivery of services to the public", "To develop policy/policies to determine a better remuneration package and indicators to determine public satisfaction", "To enhance policy/policies to motivate and monitor public servants in the delivery of services" To identify ways to enhance the public service image and the delivery of services to the public", "To examine the role of remuneration package in enhancement of the delivery of services to the public" and "To measure the correlation between the remuneration package and delivery of services to the public."

The study was very significant to both public servants and the general public who received the services in any country. It was significant to public servants to determine whether they were satisfied 
with the package they received while to the public, whether they were satisfied with the services they were receiving and the way they were being treated, which will ultimately results in customer satisfaction. This study was important because had determine if a public servant received a good remuneration package or it needs improving, will it enhances the delivery of public services to the people or it will not lead to any enhancement. This study had benefit and will make significant contributions to the researcher, public servants, government, unions, policy makers, the general public and all the other relevant stakeholders since valuable information was gathered about the relationship between a good remuneration package, work performance and the delivery of public services to the public. The information gathered can be used to make very important decisions and policies as it relates to determine what is a good remuneration package for public servants, develop policy/policies to motivate and monitor public servants in the delivery of services, develop measurable indicators to determine public satisfaction, the role of remuneration package in enhancement of the delivery of services to the public and ways to enhance the image of the public service especially with the delivery of its services to the public.

\section{Methods}

\section{Description of the site}

The public services of many countries were researched such as that of Guyana, Trinidad\& Tobago, The General Caribbean, Gulf countries/Gulf Cooperation Council (GCC), Republic of South Africa, Kenya and Nigeria. The public service of any country has almost the same structure. For example, in Guyana, the public service is composed of ministries with divisions and departments under their control, regional administrations, public corporations, financial entities, constitutional agencies, and military and police services. Most of the divisions and departments report to their respective ministers through their hierarchies, some ministries contain autonomous departments whose heads report directly to the Minister. Public Servants such as in Guyana are either employed on the pensionable establishment or on contract and are paid on a salary scales.

\section{Description of the study carried out}

This study was carried out by reviewing other studies, publications, books, websites, journals and articles carried out in the area of the remuneration package Public Servants and its impact on the enhancement in the delivery of services to the public in countries such as Guyana, Trinidad \& Tobago, The General Caribbean, Gulf countries/Gulf Cooperation Council (GCC), Republic of South Africa, Kenya and Nigeria. The review of the literatures in this context reveals that a number of researchers have emphasized the importance of remuneration package and its enhancement in the delivery of services to the public. The research has been carried out keeping in mind the objectives and research questions in this study.

\section{Description of the method used}

The method used was of qualitative nature where secondary data was gathered to answer the research questions. The secondary data were collected through the use of literature reviews from agency that are responsible for the preparation of remuneration package, websites, articles, journals and past research that were of similar nature in different countries. The countries public services that were chosen for this document research were Guyana, Trinidad and Tobago, The General Caribbean, Gulf countries/Gulf Cooperation Council (GCC), Republic of South Africa, Kenya and Nigeria. The targeted population was public servants of these countries.

\section{Results}

\section{Remuneration package in public service and its relation to service delivery in different countries public services.}

\section{Guyana}

According to Draper, 2001, he pointed out in his research that during the period of public sector expansion in Guyana which resulted in unwieldy and dysfunctional structures. This expansion has 
brought about a deterioration of the quality of public services. In 1999 the then government set up an Arbitration Tribunal. The Tribunal's Judgment report stressed the importance of having a future pay policy to avoid further confrontational negotiations and stressed the need to start the reform process at once. He also pointed out the need for the involvement of the union into the reform process and to start implement team building in Ministries and departments. The government then designed a Public Service Reform project and one of its key components is, "Improving service delivery and efficiency through an overview of the public service function and institutional capacity assessments. (Draper, 2001).

The public service of Guyana has a very important mandate to its citizen which includes providing services such as education, housing, law, and infrastructure. This is a major responsibility with which the Public Service and its personnel are expected to deliver with efficiency and dispatch. (Report on the Commission of Inquiry into the Public Service of Guyana, 2016).

In the year 2016, saw the government of Guyana invested heavily into the Commission of Inquiry (COI) into the Public Service and in keeping with one of the terms of reference, which speaks about the principles on which wages and salaries of public service should be fixed and more specifically the basis on which the levels of remuneration for various levels of Public Servants is determined. This reviewed the compensation system of public service and in addition, the determination of wages and salaries, current salary structure, at various levels of public servants, job grading, staff performance evaluation and pay for performance for incremental movement within the salary scale. This report clearly highlighted the following:

1. There is a fourteen (14) grade salary scale that is used today to pay public servants in the different positions by the ministries/agencies/regional administration.

2. The Establishment Division of the Ministry of Finance determines the pay ranges and incremental levels for public servants. The COI also pointed out that $13 \%$ of the 2016 budget which was $\$ 230$ billion dollars accounts for the employment cost.

3. The GPSU is the only union representing workers in the public service. It clearly stated that, "Over the last two decades, the Government of Guyana has violated its contractual and legal obligations to bargain in good faith with the Union and has instead unilaterally imposed acrossthe-board salary increases of 5-8 percent (\%), provided for in the annual National Budgets, without regard to individual job performance." (Report on the Commission of Inquiry into the Public Service of Guyana, 2016)

4. Persons who were hired on the pensionable establishment, at the end of their service received a gratuity and a pension once they meet certain eligibility criteria and those of contract received a gratuity allowance of $22.5 \%$ of their basic salary payable every six (6) months which is subject to a successful performance review. They do not receive a pension.

5. Along with a basic pay, some categories of public servant received allowances that directly or indirectly linked to job performance. Such allowances are meals, uniform, telephone, station allowance, traveling, passage assistance, vacation allowance, entertainment, duty and responsibility. It clearly highlighted that apart from the regular salary increase, allowances have not been increased for over twenty five (25) years to reflect current market value.

6 . It is of the view that wages and salaries are well below acceptable levels and with the growing number of contracted employees receiving a higher pay than the other has negatively affected work performance and employee morale.

7. It clearly stated that, "the Public Service faces ever-increasing pressure to adjust to changing global, political, economic, social and technological trends. It is, therefore, important that any restructuring and reform initiative undertaken be treated as a matter of priority and urgency to ensure that it deliver services with high levels of efficiency and effectiveness that must meet the expectations of the general public, the national strategic objectives and international obligations." (Report on the Commission of Inquiry into the Public Service of Guyana, 2016).

The COI made two (2) recommendations based on the above findings, namely:

1. That an Organizational Restructuring be undertaken in two Phases. In the First Phase, emphasis should be placed on rationalizing the status of pensionable and contract employees and the 
'de.bunching' of employees in the Salary Structure and in the second Phase continue the restructuring process by way of a thoroughly conducted job evaluation study.

2. That Compensation Management be accepted as a key Human Resource Management function overseeing the full range of Compensation Management practices such as grading of jobs, and computation of salary structures.

Other recommendations made were as followed:

3. That the Department of the Public Service should be solely responsible for Wages and Salaries Administration in the Public Service. Therefore, the responsibilities undertaken by the Establishment Division of the Ministry of Finance relating to fixing salaries should be assigned to Public Service Management.

4. Collective bargaining negotiations and industrial relation between GPSU and negotiation responsible Ministry on behalf of the Government should be in good faith and in keeping with international standards (CARICOM AND International Labor Organization).

5. Retain the fourteen grade salary scale but maintained a more rational and attractive value on the minimum, midpoint and maximum point of payment so as to avoid overlapping

6. A salary review committee should recommend to the National Assembly the salaries of the President, Prime Minister, Members of Parliament, Permanent Secretaries and other high ranking officers. (Report on the Commission of Inquiry into the Public Service of Guyana, 2016)

In the year 2017, the government of Guyana in its 2017 Budget has made and implemented some changes as it relates to salaries for public servants. This was done with the view to lead the pathways to a good life. According to a brochure disturbed by the Ministry of Finance in the year 2017 title "At a Glance Budget 2017" in highlighted that seven thousand, six hundred public servants will benefits from tax free salaries, there was an increase in the income tax threshold, persons earning a particular salary will have one third of their income tax free, and personal income tax decrease for persons earning a particular salary per annum. (Ministry of Finance, 2017).

\section{Trinidad and tobago}

In Trinidad and Tobago, their public service is made up of a diverse workforce where the central agency that is the personnel department is responsible for determining and /or advising on pay and other terms and conditions for a wide spectrum of public sector employees. The current initiative in the public sector reform in this country saw that importance in the, "enhancement of the quality and delivery of Public Services" This is the overall strategic objective of the reform effort. Under this reform they introduce the Opinion Leaders Panel Survey as a feedback system for performance based management in the public service. Feedback will be taken from a representative sample of the population on government service delivery as it related to efficiency, effectiveness, equity, relevance and the information gathered will be used by policy makers to either modify their current service delivery approach or revise strategic objectives as required. In Trinidad and Tobago, a Monitoring and Evaluation Policy within the Public Service was being developed to foster a culture of managing for results. This policy was formed with the participation and collaboration of key stakeholders. (Riley and Nunes, 2004).

Chapter V of Trinidad and Tobago (T \&T) Civil Service Act Chap. 23:01 makes provisions for the payment of remuneration and increments to public servants. It stipulated how and when these officers should be paid. The Act also makes provision for the personnel department to keep review the remuneration payable to civil servants and provide and establish procedures for consultation and negotiation for remuneration between its department and appropriate recognized association(s). The Act also makes provision for the Minister of Finance from time to time to make recommendations on remuneration. On the other had the Constitution of $\mathrm{T} \& \mathrm{~T}$ makes provision for a Salary Review Commission which is mandated from time to time review the salaries and other terms and conditions of service of the offices falling within its purview. This has to be done with the approval of the President. The offices that fall under its preview are being paid different benefits. Salary scales at the lower levels employment in T\&T civil are comparable to the private sector but are competitive with the private sector for the middle and senior management level. 
Wage negotiation which includes wage increases, travelling and other allowances and leave entitlements for monthly paid officers in the public service is between the representative associations who bargain collectively with the Chief Personnel Officer (Known as the employer of State employees under the IRA). The agreement of the negotiation is enter into a Memorandum of Agreement and when it affects existing legislation; it is amended accordingly to give effect to the agreed position. On the other hand for the daily paid officers, the terms and conditions of employment are through a collective agreement (collective bargaining) entered into by their recognized majority union and the Chief Personnel Officer after collective bargaining.

There is a national Information and Communication Technology (ICT) strategy, dubbed "fast forward" and identified inter alia e- Government, as a key driver for the delivery of efficient and effective citizen-centered services. This give birth to the GovNeTT Communications Backbone and it provides a number of benefits such as improved citizen experience when interacting with Government agencies and Ministries and increased efficiency of government operations, etc.

In order to determine performance management in the public service of $\mathrm{T} \& \mathrm{~T}$, two process was carried out namely, process of developing and reviewing annual work programmes within individual Ministries and Departments and reporting on these to the Parliament; and the process whereby Ministries and Departments account to the relevant central agency (currently the Ministry of Planning and Development) for expenditure planned and incurred under the Public Sector Investment (or Development) Programme. There is an initiative to develop a unified system for the identification of excellent performance or otherwise on the part of Ministries and Departments. On the other hand employee performance in T\&T has received the most attention. The Office of the Prime Minister, in January 1995 published a manual to assist Reporting Officers to manage performance in the Public Service It introduced a New Performance Management System which would effectively replace the old system of staff reporting. In T\&T performance management initiatives existence was since the early 1960. The implementation of an integrated performance management system is of utmost importance in public service transformation agenda and is moving for its implementation. (Riley and Nunes, 2004).

\section{Barbados}

One important element in the civil service reform programme in Barbados was the creating of a customer focused government where the public sector becomes more sensitive and responsive to the needs of citizens.

\section{The general caribbean}

It is viewed that the current performance evaluation systems and tools in the Caribbean are not effective since it tends to give employees ratings on the higher end of the scale. It uses does not reflect real differences in performance and its usefulness in decision making for human resource There is no merit pay system in place.

One study findings carried out in 2013 revealed that in Jamaica and Trinidad (Davis-Cooper, 2013).

1. That the traditional compensation forms emphasized that base pay might not have been sufficient motivators of top management's performance.

2. The compensation policies and practices remained mostly unchanged since independence for the larger public service.

3. It stated that employee performance management tools assist management in identifying and measuring the gaps in employee performance.

4. Adequate pay and rewards play a motivating role in employee performance as well as employee retention.

5. When a consensus cannot be made between the employees and employer on salaries and conditions of service, employees' representative associations often engage in negotiations with employers on behalf of workers. Several conditions are taken into account during the negotiation such as the state of the national economy, the company's financial standing, the compensation of comparative positions in the wider labour market and the cost of living. 
The study concluded that, "in order to attract and retain employees with the necessary expertise to accomplish the strategic organizational outcomes, governments in the English-speaking Caribbean needed to provide adequate salaries, allowances and perquisites" (Davis-Cooper, 2013).

\section{Gulf countries/Gulf Cooperation Council (GCC)}

In countries that make up the Gulf such as Saudi Arabia, United Arab Emirates, Oman, Yemen, Kuwait, Qatar and Bahrain among others, remuneration packages consist of a basic salary and allowances, such as housing, transport, utilities or other miscellaneous allowances, these two together forms a guaranteed take-home pay. The primary objective for introducing the different allowances was to attract and support the foreign workforce. The most common benefits across the Gulf were assistance extended in the form of children's education allowances, health-care benefits and annual vacation travel (or an equivalent cash amount to nationals). The researcher noted that the competitive remuneration package along with a tax free environment and a comfortable lifestyle has attracted talent from around the globe. In the absence of a robust performance management system, increases are given across the board, thus leaving high performers feeling short-changed, and weak performers none the wiser as to how reward is related to their performance. (Kapoor, https://www.haygroup.com/downloads/uae/2013-10-changingtimes reward practices in the gcc countries - final.pdf).

\section{Republic of south africa}

A research from a booklet title "Salaries and Benefits in the Public Service" by the department of Public Service and Administration, Republic of South Africa indicated in its introduction that, "...government has come up with a comprehensive remuneration package that is prudent, forward looking and paves the way towards improving service delivery and public service performance and at the same time, ensuring improved conditions of service for all public servants." (Salaries and Benefits in the Public Service Booklet, Department of Public Service and Administration, Republic of South Africa) The booklet revealed the following:

1. Public Service Act appointees from GS 1 to 10 and in 2008/2009 salary adjustment received a package which includes a basic salary, the annual service bonus (1/12 of basic salary) and the Employer contribution to the Government Employees Pension Fund.

2. To retain and recruit professionals, their wage agreement provides development of occupational specific dispensation for Nurses, Educators and Legally qualified employees.

3. Employees appointed on permanent basis are required to be members of the Government Employees Pension Fund. This fund provides benefits such as retirement (normal and early), resignation, death (whether in service or after retirement), funeral benefits, orphan's annuity, ill health benefits and discharge benefits base on any of the reasons listed below:

- the abolition, reduction, reorganization or restructuring of the member's post;

- to promote efficiency in the department;

- injury on duty, and for

- Medical reasons.

4. Other benefits received include housing, medical, service bonus, different types of leave dispensations which include annual leave, normal sick leave, temporary incapacity leave, leave for occupational injuries and diseases, maternity leave, family responsibility leave, adoption leave, special leave and leave for office and also on working time which includes averaging of hours of work for shift workers, working on Sundays and public holidays, night work and overtime work.

\section{Public service transformation through constitution review, the kenyan experience}

This process engages in a constitutional reform that provides a Framework for Efficient and Effective Public Service Delivery in Kenya. This study stated that the 2010 Constitution indicated that efficient and effective public service delivery is not a privilege in a democratic environment. This constitution contains principles and elements that will have both direct and indirect impacts on public sector performance, reform, and transformation namely Productivity; Marketization; Service 
Orientation; Decentralization; Policy and Accountability. Countries in South Africa have adopted these principles and it has increase efficiency and effectiveness through marketization of public services.

The diagram below proposes a framework for efficient and effective public service in Kenya and further proposes that new role of the public servant; to ensure efficient and effective public service delivery in devolved government. To ensure its success, the entire public service will have to response to the needs of Kenyans through policy processes that have involved participatory processes with the citizens.

(https://www.capam.org/offerings/articles/2015/public_service_transformation_through_constitution_ review.html).

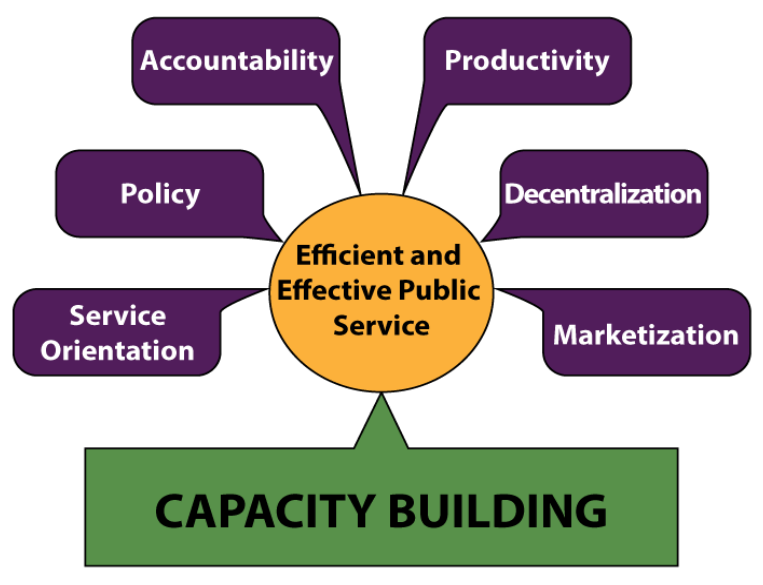

Diagram 1. Showing the frame work for efficient and effective public service delivery in kenya

Employee satisfaction and morale are considered two most important drivers of performances of employees. Wages and salaries (monetary factors) are considered important for employees; one should also look at non-monetary factors. One research title, "Improving Public Sector Efficiency: Challenges and Opportunities" by Curristine et al, 2017 stated that "...although governments often are model employers and their wage policies reflect equity concerns as well. Wages are also important for attracting and retaining qualified staff, especially in case of skill shortages. Performance-related pay initiatives appear to have a low impact on staff motivation."(Curristine et al, 2017) This research also highlighted the following:

1. That in some Organization for Economic Co-operation and Development (OECD) countries public sector wage difference is the highest at the lower end employment ladder and decrease as you move up the employment ladder.

2. The impact on the quality of service delivery and policy effectiveness is unclear.

3. Negative effects of performance measurement/management.

4. Union representation is rather high in the public sector in most countries but the impact of unions on issues of efficiency and effectiveness is unclear.

5. Image plays an important role in public sector. It stated that the unattractive image of the public service in United States makes many educated students to pursue their careers in the private sector.

6. OECD has introduced Performance Information (PI) into the public service and has seen improvement in the monitoring of performance. It provides details to the government on what is working and what is not. This research stated that, "PI acts as a signaling device that highlights problems with programmes and with service delivery, as well as good practice. Once a problem or poor performance is identified, different steps can be taken to improve performance.”(Curristine et al, 2017) 


\section{Nigeria}

A research carried out in the Nigerian Public sector, 2015 title "Low Income and Diminishing Productivity in Nigerian Public Sector" highlighted that many commissions were set up both in the colonial and past colonial periods to handle wage reviews. This was influenced by labor unrests resulting from the desire for better salaries and conditions of service. This research pointed out that "ILO perception of fair income complimented Frederick Taylor's view in his Scientific Management Theory, a classical school which focused on productivity of individual workers. Taylor posited that money was the way to motivate workers to their fullest capabilities. Taylor felt that such financial incentives would induced workers to produce more so that they might earn more money."(Obasaolufemi, 2015) It further pointed out that, "The remuneration of low income to workers in the public sector has psychological, economic and social implications on their attitudes towards work in a workplace." (Obasaolufemi, 2015) This research pointed out that reforms that related to public servants fail because of its implementation or execution. It stated that (...major causes of the failure of wage and salary reforms of the past are over-politicization of the policy, systemic breakdown, distrust and suspicion among the political gladiators and labor representatives, discontinuity, corruption, betrayal of political leaders as well as bureaucratic bottleneck."(Obasaolufemi, 2015)The recommendations made for Palliative measures for reducing the effects of low income on public workers are as followed control of inflation, provision of incentives, tax rebate, regular promotion and annual increment to staff and introduction of performance-related pay. This research highlighted that public sector organizations were created for the purpose to provide good quality services to citizens at low and acceptable cost. The research concluded that, " the government should be able to restructure the income of public servants equitable to what is obtainable in other part of the world, there is need to reduce the size of the civil service to enable the governments to sustain and finance a smaller and better paid civil service over time. An efficiencybased incentive scheme that links reward to performance may provide strong motivation. Incessant Political interference, which has seriously undermined the credibility and confidence of the public service in the design and implementation of government policy, should be minimized." (Obasaolufemi, 2015)

As it relates to Latin America and the Caribbean where Guyana is a part of, the findings highlights that the many countries central civil service suffers from inefficiency, wastage, corruption and weak capacity to provide public services. It pointed out that, "Civil servants, too, appear to be adequately remunerated, with average central government wages over two and a half times per capita GDP." (Schiavo-Campo et al, Government employment and pay in global perspective, World Bank)

As it relates to Middle East and North Africa, one of the findings highlight that in Africa, there is an inadequacy in public service delivery. The findings under these countries also pointed out that there was little policy effort devoted to streamlining the government workforce and improving its efficiency.

The finding highlights under the wage and incentive policy that there is great fiscal benefit for wage containment but this would not work in developing countries since they barely have competitive or inadequate public wages. If this takes place on real wages there will be a vicious circle of demotivation, under-performance, and justification for further reductions.

Under the design of a compensation plan, it stated that civil service compensation is determined by two main methods, namely trial-and-error method and comparison with the private sector.

\section{Discussion}

A qualitative study was carried out on the impact of a good remuneration package to public servants on the enhancement of the delivery of public services with the following objectives "To determine if a good remuneration package to public servants will lead to the enhancement in the delivery of services to the public", "To develop policy/policies to determine a better remuneration package and indicators to determine public satisfaction", "To enhance policy/policies to motivate and monitor public servants in the delivery of services" To identify ways to enhance the public service image and the delivery of services to the public", "To examine the role of remuneration package in enhancement of the delivery of services to the public" and "To measure the correlation between the 
remuneration package and delivery of services to the public." This was carried out under five research questions namely:

1. What can be considered a good remuneration package for public servants?

2. What policies are in place to motivate public servants to deliver effective services?

3. What systems are in place to monitor public servants in order to deliver effectively on the job?

4. Who determines a good remuneration package for public servants?

5. What indicators are used to determine public satisfaction with service received?

\section{What can be considered a good remuneration package for public servants?}

This research has indicated that every country has a different package payable to public servants but all included a salary and different allowances payable at different rates as shown in Guyana, Trinidad and Tobago, The General Caribbean, Gulf countries/Gulf Cooperation Council (GCC), Republic of South Africa, Kenya and Nigeria. The difference in each country is that the salary structures payable are different and different allowances. Some countries have more allowances to offer than some. This was reflected in Davis-Cooper, 2013 finding in that in order to attract and retain employees with the necessary expertise to accomplish the strategic organizational outcomes, governments in the English-speaking Caribbean needed to provide adequate salaries, allowances and perquisites. It was also reflected in the research conducted in the Gulf countries which pointed out that the competitive remuneration package along with a tax free environment and a comfortable lifestyle has attracted talent from around the globe.

Therefore, in order to consider a good remuneration package for public servants, governments of each country has to look at the economic factors of a country and what it is able to offer public servants to have a decent and comfortable standard of living. A good remuneration package must include an adequate salaries and suitable allowances payable in a tax free environment, a government pension fund and its perquisites.

\section{What policies are in place to motivate public servants to deliver effective services?"}

This literature clearly shows that there is not much done by employers to motivate public servants to deliver effective services. No effective policy (policies) has been highlighted other than what is being recommended in some countries like Guyana. Every public service position comes with a package which includes a salary and allowances but it clearly shows the package is not really satisfying and much is not done to change it, as the years goes by. A COI in Guyana highlighted that if the government wants to ensure that it delivers services with high levels of efficiency and effectiveness to meet the expectations of the general public, restructuring and reform initiative undertaken must be treated as a matter of priority and urgency. This is a recommendation which needs to be taking seriously and put policies in place to ensure proper and efficient restructure to get effective results.

Therefore, in order to motivate public servants to deliver effective services polices needs to be formulated and implemented in keeping with current times and practices. They have to be continuously monitored and change as times goes by.

\section{What systems are in place to monitor public servants in order to deliver effectively on the job?"}

Under this research question most of the countries under study does not have any effective systems to monitor public servants in order to deliver effectively on the job. All of the countries have a Performance Appraisal system but its effectiveness is questionable. In some countries this is just a formality which is not even implemented and monitored properly. This was clearly highlighted in almost all of the countries under study. In Trinidad and Tobago, there is an exception which a study highlighted that they introduced the Opinion Leaders Panel Survey as a feedback system for performance.

Therefore, in order to monitor public servants in order to deliver effectively on the job, the government needs to revise it current systems especially that of the performance appraisal/evaluation to keep with the job description and job specification of the position. This needs to be properly 
implemented and monitored by well-trained individuals in this area. New system such as that recommended in Trinidad and Tobago can be adopted or even introduced a suggestion box.

\section{Who determines a good remuneration package for public servants?}

This study pointed out that every country has their own system, person (s) and or department that is responsible for the determination of a remuneration package. Even though this is so, this study highlights that in almost all the countries under study, the unions did not really play an effective role in making effective contributions on its employee's behalf, in the determination of the remuneration package which was clearly indicated in COI in Guyana.

This study indicated that in;

1. Guyana, it is the Establishment Division of the Ministry of Finance who determines the pay ranges and incremental levels for public servants. For pay increases, there is consultation between unions and negotiation ministry on behalf of the government.

2. Trinidad and Tobago, this includes the personnel department reviews the remuneration payable to civil servants and provides and establishes procedures for consultation and negotiation for remuneration between its department and appropriate recognized association, the Minister of Finance from time to time makes recommendations on remuneration and a Salary Review Commission which is mandated from time to time review the salaries and other terms and conditions of service of the offices falling within its purview. Wage negotiation for monthly paid officers in the public service is between the representative associations who bargain collectively with the Chief Personnel Officer and for the daily paid officers, the terms and conditions of employment are through a collective agreement (collective bargaining) entered into by their recognized majority union and the Chief Personnel Officer after collective bargaining.

Therefore, to determine a good remuneration package for public servants and the necessary increases, every country must have an independent body to review remuneration packages for public servant. Where this is not possible every country system, person (s) and or department that is responsible for the determination of a remuneration package must work collaboratively in the interest of public servants to determine the best package for them.

\section{What indicators are used to determine public satisfaction with service received?}

Most of the countries under study did not mention any indicators to determine public satisfaction with service received. Trinidad and Tobago has an Opinion Leaders Panel Survey as a feedback system for performance. The indicators to be used were not mentioned. Public satisfaction is very had to measure but indicators can be formulated which need to be specific and measurable in keeping with the service provided. Some indicators could be timeliness, value, adequacy, quality, satisfaction/appreciated, recommending the service or revising it if needs and desires are met, reliability, accessibility, professional appearance, attention and care given by public servants.

In general, the major findings discovered were that in almost all public service under study, there were massive public sector reforms to tackle work performance and delivery of services. The determination of a remuneration package/ wage structure for the various categories of public servants is a problem, public service delivery is a problem in most countries as pointed out in Africa, in Latin America and the Caribbean and the employee performance tools used is ineffective and needs to be revised.

The result of this study shows that a good remuneration package to public servants will enhance the delivery of public services. Further research on this study should be done quantitatively in a specific country public service to determine the correlation between the remuneration packages and enhance service delivery. It is recommended that:

1. Guyana Public Service be selected to carry out the quantitative research by having the sample size being selected from its two most important, largest and their obligations in the delivery of very important services to the public such as health, housing, water, etc., (Ministry of Communities and Ministry of Public Health.

2. The instruments of data collection should be that of questionnaires distributed to junior and middle level public servants and interviews with senior government officials and union officials 
since you will be able to get hand on data for your study. Likert scale method should be applied when setting the questionnaire questions and design an interview schedule with open and close ended questions.

3. Determine two hypothesis for the study with an independent and dependent variable.

4. Data should be analyzed using SPSS to determine the mean, median, mode and standard deviation according to researcher question/cluster, graphs and charts will also be used to analyze each question on the questionnaire according to research question/cluster. Correlation statistical technique can be applied to gauge the relationship between factors used in the study. Regression analysis can be carried out to find the impact of remuneration package on the enhancement in the delivery of services to the public. The hypothesis can be also tested to determine acceptance or rejection of the null/alternative hypothesis by using the data collected from the questionnaires, which can then be subjected to a T testing at 0.5 level of significance. Also, Analysis of Variance -ANOVA technique can be used to test the hypothesis and Chi-Square test can be performed to check the significance.

5. A good remuneration package must include an adequate salaries and suitable allowances payable in a tax free environment, a government pension fund and its perquisites.

6. Polices needs to be formulated and implemented in keeping with current times and practices. They have to be continuously monitored and change as times goes by.

7. Review, implement and monitor employee performance systems/tools by well-trained individuals in this area. New system such as that recommended in Trinidad and Tobago can be adopted or even introduced a suggestion box.

8. Every country must have an independent body to review remuneration packages for public servant. Where this is not possible every country system, person (s) and or department that is responsible for the determination of a remuneration package must work collaboratively in the interest of public servants to determine the best package for them.

9. Indicators needs to be formulated which need to be specific and measurable in keeping with the service provided. Some indicators could be timeliness, value, adequacy, quality, satisfaction/appreciated, recommending the service or revising it if needs and desires are met, reliability, accessibility, professional appearance, attention and care given by public servants.

10. Introduce increment pay for performing workers.

\section{Conclusion}

The researcher interprets and concludes that there is a strong relationship between public servants receiving a good remuneration package and the enhancement in the delivery of the public service to the people of any country such as Guyana. However, the government should not totally depend on remuneration package to public servants in the enhancement of the delivery of services to the public. They should look at other means such as strengthening policies and measurements as it relates to work performance of public servants, motivational training especially in customer service and not forgetting the use of technology which can greatly enhance work performance and service delivery in the public service.

\section{Acknowledgement}

I would like to take this opportunity in thanking my family especially my husband Jaigobin Jaisingh and my guide Dr. Jayanthi in assisting me in the completion of this Article. I would also like to thank all personnel from Texila American University for giving me this opportunity.

\section{References}

[1].At a Glance Budget 2017 Brochure, Ministry of Finance, Guyana Constitution of the Co-operative Republic of Guyana, Act No. 2 of 1980, Article 232 (1). Retrieved from

http://www.wipo.int/edocs/lexdocs/laws/en/gy/gy009en.pdf.

[2].Curristine et al, 2017. "Improving Public Sector Efficiency: Challenges and Opportunities", OECD Journal on Budgeting, Volume 7 - No. 1. Retrieved from https://www.oecd.org/gov/budgeting/43412680.pdf. 
DOI: 10.21522/TIJMG.2015.04.01.Art003

ISSN: $2520-310 \mathrm{X}$

[3].Davis-Cooper, Gloria. 2013, "Capacity Building and Developmental Outcomes in Two English- Caribbean Countries" GSTF International Journal of Psychology (JPsych) Vol.1 No.1, DOI 10.7603/s40790-014-0003-6. Retrieved from https://www.globalsciencejournals.com/content/pdf/10.7603\%2Fs40790-014-0003-6.pdf.

[4].Draper, Gordon M. 2001, Public policy management and transparency: civil service, the civil service in Latin America and the Caribbean: situation and future challenges: the Caribbean perspective, working paper. Retrieved from http://services.iadb.org/wmsfiles/products/Publications/558038.pdf.

[5].https://www.capam.org/offerings/articles/2015/public_service_transformation_through_constitution_review. html

[6].Kapoor, https://www.haygroup.com/downloads/uae/2013-10-changingtimes reward practices in the gcc countries - final.pdf.

[7].Obasaolufemi, 2015. "Low Income and Diminishing Productivity in Nigerian Public Sector" Arts and Social Sciences Journal, 6:113.doi:10.4172/2151-6200.1000113. Retrieved from https:/www.omicsonline.org/openaccess/low-income-and-diminishing-productivity-in-nigerian-public-sector-2151-6200-

1000113.php?aid=59234\&view=mobile.

[8].Riley, Beresford and Nunes, Micheline, 2004. "Public sector reform programmes and performance management in Trinidad and Tobago", A Country paper for the Commonwealth regional seminar on integrated performance management systems in the public sector for the Caribbean region. Retrieved from http://unpan1.un.org/intradoc/groups/public/documents/CARICAD/UNPAN017179.pdf.

[9].Salaries and Benefits in the Public Service Booklet, Department of Public Service and Administration, $\begin{array}{lllll}\text { Republic of } & \text { South } & \text { Retrieved }\end{array}$ http://unpan1.un.org/intradoc/groups/public/documents/CPSI/UNPAN034586.pdf.

[10]. Schiavo-Campo et al, Government employment and pay in global perspective: A selective synthesis of international facts, policies and experience, World Bank Retrieved from

http://citeseerx.ist.psu.edu/viewdoc/download?doi=10.1.1.200.82\&rep=rep1\&type=pdf.

[11]. Trinidad and Tobago Civil Service Act, Chapter 23:01 Retrieved from

http://rgd.legalaffairs.gov.tt/laws2/alphabetical_list/lawspdfs/23.01.pdf. 